\title{
Old Money, Networks and Distinction: The Social and Service Clubs of Milan's Upper Classes
}

\section{Bruno Cousin and Sébastien Chauvin}

Although research on bourgeois urban sociability has sometimes provided descriptions of elite social clubs (see for instance: Baltzell, 1987; MilneSmith, 2011; Pinçon \& Pinçon-Charlot, 1989, 1998, 2007; cf. Khan, 2012), existing studies have mostly remained monographic, while showing little interest for the space of clubs as a distinct object of investigation. In contrast, developing an approach inspired by Bourdieu's symbolic relationalism (Bourdieu \& Wacquant, 1992), this chapter conceptualises the local space of social clubs and of (some) service clubs as a diversified universe of practices and meanings, in which various institutions, individual strategies and representations are united through interdependence and mutual references. To develop this approach, we take the case of Milan

\section{B. Cousin $(\bowtie)$}

Centre d'études européennes and Department of Sociology, Sciences Po, Paris, France

S. Chauvin

Institut des sciences sociales, University of Lausanne, Lausanne, Switzerland

R. Forrest et al. (eds.), Cities and the Super-Rich, DOI 10.1057/978-1-137-54834-4_8 
and offer an analysis of how institutions of formal elite sociability in a major European city differentiate and position themselves and others.

By studying elite clubs in Milan-Italy's economic capital and only 'alpha' city according to both the oldest and the most recent GaWC rankings-we contribute to the sociology of Italian urban upper classes. The chapter also addresses the bustling theoretical discussion over social capital (Bourdieu, 1980) by emphasising its symbolic dimension and the meaning-making processes that accompany its deployments. It argues that the representation of social capital contributes to its reality and unequal efficacy (Cousin \& Chauvin, 2010, 2012). Some authors have aptly criticised the excessive polysemy of the concept of social capital (Ponthieux, 2006; Portes, 2010). Taking cues from these critiques, this chapter shifts focus to how actors themselves frame their social capital. Through relational analysis, it points to the particular criteria that each institution of sociability deploys to organise, mobilise, describe and legitimise the connections it weaves between its members, and to distinguish itself from its competitors.

The five institutions analysed here are the three (all-male) social clubs patronised by the traditional elites of the city (the Circolo dell'Unione, the Clubino and the Società del Giardino) and two of the oldest and most prestigious local Rotary clubs (the RC Milano and the RC Milano Sud). ${ }^{1}$ These institutions are explicitly devoted to the centralisation, actualisation, maintenance and protection of the internal networks of acquaintances that structure Milan's ruling class, and thus participate in the definition of the boundaries and differences between its fractions. Most of the data for this study were collected in 2001 and 2002, through 30 in-depth interviews with club members and officials, and ethnographic observation in the salons of social clubs and during Rotary club meetings.

The first section traces the history and social composition of each club and describes variations in their organisation of sociability. The second section details the uses and representations of internal social connections that characterise each club, while the third section insists on the dynamics of mutual distinction that they activate. We conclude by arguing that social-scientific debates over social capital must account for these games of distinction, which are part and parcel of their empirical object.

\section{The Social Space of Milan's Upper-Class Clubs}

\section{The Circolo dell'Unione: Classicism in Sociability}

The Circolo dell'Unione is sometimes designated (especially by nonmembers) as 'the club of the old nobility of Milan and Lombardy'. Yet, 
at the end of 2001 , only 60.8 per cent of its 549 members held a hereditary aristocratic title or belonged to the former nobility. ${ }^{2}$ Coming from an aristocratic family was never a requisite to join the Unione, whose name comes from the integrated sociability between nobles and high bourgeois that it fostered since its foundation in 1841. Today, therefore, the club is distinct from the nobility associations that are specifically dedicated to the management of local aristocratic heritage and the preservation of symbolic capital (De Saint Martin, 1993).

The Unione's roots, however, are clearly in the city and the region. Indeed, it brings together several groups with local origins: the scions of the Houses of Visconti, Trivulzio, Sforza, Borromeo and of other archbishops and famous condottieri (mercenary captains) who have fought each other and alternately reigned over Milan since the Late Middle Ages; the descendants of many other families who held seats in the Council of Decurions during the three centuries of the Early Modern Period (until 1796); the liberal nobility who was involved during the nineteenth century in the movement for the independence and unification of Italy; and, finally, the bourgeois dynasties of the 'industrial aristocracy' who made Milan one of the main European economic centres at the turn of the twentieth century. Until the end of the nineteenth century, the club was a space of deliberation and coordination for the city's ruling class, and was the heart of Milan's politics. It then lost this role, while retaining its functions of leisure and elite sociability, without official purpose. ${ }^{3}$

Today, the characteristics of the Unione's membership illustrate how social clubs inscribe traditional Milan elites into a common local identity. Local roots are even more salient for the oldest lineages, given that the 'Italian' nobility and bourgeoisie did not exist as such until the political unification of the country in 1861. The history of each great family, which founds its prestige and during which its social capital was accumulated, primarily partakes in the history of a region, sometimes a specific city. Thus, for a man of this milieu, to join the Unione ratifies not only his inherited social position but also his local belonging. It is impossible to run into an intruder or an unknown stranger here. The club appears to its members as a perfectly homogeneous and integrated environment:

And you know them: they are all those that could have been the children of family friends or those you heard about or which you had met when you were a child, when you were a kid. You find them back ... and others who then join little by little, who perhaps you didn't know but who are more or less compatible because they are ... they are of the same kind. They belong 
to the same group of people that we frequent normally: sons of friends, sons of friends of our parents, nephews of friends of our parents. (G., 39, lawyer, member of Unione's board)

As a consequence, almost all respondents from the Circolo dell'Unione (and from the Clubino) define their club as their 'second home', an 'extension of home', a 'place where one is a little bit like at home', with a cosy atmosphere: an enjoyable place, where they go to get a drink at cocktail hour, for lunch or dinner, to play pool, or simply to read the newspaper and spend some pleasant time among more or less close kin, friends and men of the same world. In the absence of any external gaze, the removal of self-censorship allows dispositions making up their class habitus to carry on freely:

I admit that, every time I go to the Circolo dell'Unione, I am happy and cheerful. Because I have fun, I truly feel very well. There, I find the most agreeable persons and an exceptional easiness in maintaining relations without many formalities, without any form of embarrassment (...) We are part of the same world. That's all. (A., 54, rentier)

Besides the fact that no member would run into anyone there whom he would not invite in his own home, these men can easily represent the club as an annex of their family domicile as it is a place where elite families meet and congregate. The Unione often includes several men of the same family: its frequentation is a way for cousins, or even for a father and his sons, to see each other regularly. Such encounters activate the social capital contained in a large and ramified kinship network that can thereby recognise and experience itself as a collective. There are indeed a great number of recurring alliances between the different lineages represented in the club, so that a member did not hesitate to say that 'in the end, at the Unione, we are all more or less cousins'.

Belonging to the club does not imply any obligation of attendance or participation. Although about a hundred members frequent the place regularly (two or three times a week), twice as much come more sporadically, typically in order to share a meal with other members around the large table of the dedicated restaurant, or for a business lunch or a party organised in the guest salon, which offers a vast space and a numerous, well-trained staff that many families can no longer afford at home. General member reunions take place through two annual dinners, semestrial ballots 
to accept new entrants, and the receptions held to welcome them. Club life thus appears relatively intense and the Unione does not have any problem attracting new members, even though its salons are chiefly patronised by retirees during office hours.

\section{The Clubino: Business Worlds and Renewed Prestige}

From the beginning of the twentieth century onwards, the social prestige of the Unione and its role in Milan's high society came to be challenged by another institution that imposed itself as its direct competitor and progressively established its pre-eminence. In 1901, a group of young men close to the Unione ${ }^{4}$ founded the New Club (giving it an English name). They did not quit the oldest club, however, but sought to create a place that would be less family-oriented and where it would be possible to gamble, which implied selecting members a little more through economic criteria. In addition, many members of the New Club shared a common modernist worldview embracing the realms of politics, the economy and technical progress. Among its leading figures were famous engineer and businessman Giulio Ceretti as well as entrepreneur Ettore Bocconi (son of the founder of Italy's main business school, located in Milan). However, its model of sociability remained that of an English-style gentlemen's club. Its members were strongly attached to gender segregation: until the late 1970s, the new club had no guest salon (foresteria) where members could have received their families (by contrast, the Unione set one up in 1910). The club was renamed Clubino ('Small Club') in 1947.

When asked about the Clubino today, members of other clubs tend to stigmatise its 'recent' character and reduce the identity of the institution to the social position of its members, pointing its privileged ties with the world of work and business. In 2001, among the presidents of the 100 first Italian industrial and commercial groups, 98 were men and 67 of them headed family-controlled companies. Among the latter, eight were members of the Clubino: Giovanni Agnelli (Fiat), Marco Tronchetti Provera (Pirelli and Telecom Italia), Bernardo Caprotti (grocery stores), Gian Marco Moratti (oil), Guido Barilla (food), Carlo Camerana (cement), Rocco Bormioli (glass) and Alberto Falck (renewable energies). A dozen others had relatives bearing their surname among the Clubino's members, and other top industrial families represented in the club-like the Marzottos (textile and fashion) - had delegated the executive leadership of their group to a manager but retain ownership and financial control over it. 
In addition, the Clubino also counted numerous corporate and investment bankers, such as Gerardo Braggiotti (Lazard), who was seen as one of the kingmakers of Italian Capitalism, and the future chairman of Mediobanca Gabriele Galateri di Genola; prominent business attorneys such as Marino Bastianini and Alberto Rittatore Vonwiller, who headed the largest Italian law firm (Carnelutti S.L.A.); press magnates like Carlo Caracciolo di Castagneto (La Repubblica); and Luca Cordero di Montezemolo, chairman of Ferrari (Fiat group), who in 2004 would become president of Confindustria, the main Italian employers' organisation.

However, the club would not welcome individuals whose wealth and family's reputation do not go back at least to one or two generations. True, Clubino members are generally men who have been able to perpetuate or reconquer, through their professional activity, a position in the field of power (Bourdieu, 1996), which, in Milan, is essentially economic and financial. Yet, they also possess numerous quarters of nobility or high bourgeoisie: in 2001, 25 per cent of the 629 members carried an aristocratic title. Thus, their social status is at once inherited and renewed. An interviewee told us that, as he was congratulating his friend Count Gaddo della Gherardesca for being on the cover of the business magazine Capital, the latter replied that this was not much for someone whose family is already featured in Dante's Divine Comedy. In addition, not only are aristocratswho are big holders of inherited social and symbolic capital-numerous in the club but they also come from all major Italian cities. Indeed, more than the Unione, the Clubino's model of elitism is national and even international: in the early 2000s, 18 per cent of its members had their main residence in another Italian region than Lombardy and 13 per cent abroad. ${ }^{5}$

While representing 'a type of Italy where there are many excellences' (as a board member told us), the Clubino selects individuals endowed with inherited social and symbolic capital as much as economic and, to a lesser extent, cultural capital. According to another board member, this makes it 'something halfway between a large family and a lobby'. This combination of characteristics also contributes to its dominant position within the space of Milanese clubs.

\section{The Società del Giardino: Forever Third}

Although the Società del Giardino is similar to the two previous clubs by its statutes, its membership has never participated in the local and national fields of power to the same extent. The Giardino was founded in 1783, 
but was originally just a bocce (bowls) association of merchants and traders, before becoming the club of a fraction of the propertied bourgeoisie. It often organised its sociability by imitating that of its two competitors, although it was excluded from the dense networks of mutual acquaintance connecting the Unione and the Clubino.

While speaking to an interlocutor familiar with the two other clubs, the members of the Giardino are quick to point what they consider the advantages of their own: (1) its anteriority (which other clubs often comment sarcastically with a reminder that it was initially just a 'bowls society'); (2) its 'openness' (which the others stigmatise as lower social selectivity, to which the Giardino had to accommodate itself); (3) its limited membership (about 450 in 2001), presented as if quantitative limitation had to compensate for the lesser quality of its members; (4) the luxury and size of its building-about which the others stress that it is occasionally rented out (e.g. to Rotary clubs), thereby renouncing the segregation and exclusivity that, according to them, befit social clubs' premises; (5) the organisation of cultural lectures (mocked for their school-like character); (6) the use of the club for artistic events and semi-public parties, which the Unione and the Clubino regard as ostentatious and therefore unsuitable to club sociability, supposed to be based on discretion. In this regard, it is symptomatic that the members of the Giardino consider the Golden Salon, which hosts the events and parties, as their club's main room, whereas life at the Clubino or the Unione is organised around the sala soci, the large room where chats and collective conversations take place and that is strictly reserved to members.

Giardino members themselves describe their club as a site of activities and services more than as a collective actor or a 'collective personality' (to quote an expression used by the other Milan social clubs). Contrary to the members of the Unione and the Clubino, they also never use the word sodalizio (i.e. association, fellowship, group united by solidarity) to refer to their club. This can be explained by the absence of dense networks and the scarcity of strong ties, not only with the other clubs but also between the members of the Giardino. Few of them see each other elsewhere or are related by family ties, as is immediately perceptible through their general use of the formal ' $L e i$ ' to address each other, when the informal ' $t u$ ' is not only widespread but required in the two other clubs. Indeed, although membership can sometimes constitute a family legacy, this is less usual than at the Unione and the Clubino, which likens co-optation to the Giardino to how admission takes place in the most prestigious Rotary clubs. 


\section{The Rotary: An Anti-Model at the Margin of Social Club Sociability}

The first Italian Rotary club was founded in Milan in 1923 by 14 renowned entrepreneurs, professionals and international executives (among whom an Englishman, an Irishman, a Scotsman and a Canadian). However, despite the club being successful from its start and attracting some of the biggest business figures and politicians of the city, the American origin of the Rotary organisation and the way it fostered international links drew suspicion from the Fascist regime. In 1938, judging that the political situation had become unbearable following the promulgation of the first Racial Laws, the club decided its own dissolution. It was re-established in 1947 and reincorporated into the Rotary International, within which it is still known today as the RC Milano. Subsequently, the Rotary clubs multiplied quickly during the second half of the twentieth century: from one club in Milan until 1951, there were 5 in 1961 (among which the $R C$ Milano Sud, founded in 1958), 10 in 1971, 17 in 1981, 22 in 1991 and 30 in 2001.

Co-optation in a Rotary club depends on a potential member's professional career and success, most of the time in business but also in other domains such as medicine, higher education or (more rarely) culture. That is why, compared with members of social clubs, Rotarians occupy a class position that is less often inherited and better endowed with validated cultural capital. In 2001, 84 per cent of the 2140 Rotarians of Milan's clubs held a higher education degree, when the rate was only 69 per cent at the Clubino and 60 per cent at the Unione. For many of its members, the Rotary is a late achievement, an institution to which they are introduced by a friend or colleague, a form of sociability whose codified character they discover at the moment of admission and which requires a period of learning.

For many interviewees from the RC Milano Sud (one of the oldest in the city), affiliation to the club felt like a new experience of participation to the internal sociability of Milan's bourgeoisie. In joining the Rotary, they celebrate an elite past that is not directly theirs. Their narratives show the integrating function of Rotary sociability, in contrast with social clubs, who maintain and densify a pre-existing relational network:

The Rotary, indeed — but this is something personal, a gift it made to meput me in contact with the social fabric, the Milanese networks, the city of 
Milan, Milan's families, the reality, the histories, the habits of who already lived here. Stories, accounts... The knowledge of what was happening in such and such street at the time, the story of such and such family... I often listen to stories about 'When we were doing such and such'... Thus I've had access to a little bit of the history of Milan, I felt better integrated. And this, for me, it's a pleasure and it's important. (P., 41, engineer)

The Rotary also differs from social clubs by the activities it organises: mandatory bi-monthly dinners, guided group tours to 'tighten the links between members'; conferences most often held by members and whose subjects relate to the profession of the speaker; charitable and humanitarian initiatives; twinnings with foreign RCs; attribution of scholarships; distribution of the magazines and books published by Rotary International and Rotary Italy.

These differences in social composition and internal organisation are correlated with modalities of co-optation/admission proper to each institution. At the Clubino and the Unione, the process consists in a combination of interpersonal consensus and ritual formalism. The main task of club officials and members is to organise the induction of their close oneswho they always have known were likely to enter the club (with which they often were already familiar as children)-rather than judging the social value of individuals external to the group. By contrast, Rotary clubs (and to a lesser extent the Giardino) base the assessment of applications less on prior acquaintance with the applicants and instead employ more bureaucratic selection methods, including criteria supposed to objectivate and measure the personal merit of each candidate. Several steps, interviews and analyses of curricula regulate the process of admission in a RC, whereas at the Clubino, in the words of one of its board members:

We can accept a new member in ten minutes, through a one-round discussion. We ask 'who knows so-and-so?' and if everyone knows him, if everyone knows his family and if he never left with another member's wife [laughs], then he only has to sign and he is a member. Conversely, others remain all their lives on the waiting list, because they may be rich or important or what have you... We never heard of them. (F., 40, president of a sport club)

It is still necessary to go through a ballot, but the filtering role of the Board (who continually consults the other members through discussions and requests for advice) is such that officially presented candidates are almost never blackballed. Indeed, the responsibility that weighs on the 
proponent of the applicant and on his two sponsors is such that a rejection would trigger their own exclusion: it would disavow them as peers capable of looking after the group's collective social capital and would call for their resignation from a club that, thereby, would have questioned their judgement. In 2007, when Alessandro Benetton (one of the heirs and top managers of the Benetton Group) and two other candidates were simultaneously voted against, the entire Board of the Clubino, in addition to their proponents and sponsors, tendered their resignations (Table 8.1).

Table 8.1 The space of co-optation procedures in Milanese clubs

\begin{tabular}{|c|c|c|c|c|}
\hline & Clubino & $\begin{array}{c}\text { Circolo } \\
\text { dell'Unione }\end{array}$ & $\begin{array}{l}\text { Società del } \\
\text { Giardino }\end{array}$ & $\begin{array}{l}\text { Rotary } \\
\text { clubs }\end{array}$ \\
\hline $\begin{array}{l}\text { Blocking minority during } \\
\text { vote }\end{array}$ & $1 / 8$ & $1 / 6$ & $1 / 4$ & $1 / 3$ \\
\hline $\begin{array}{l}\text { Pre-selection of applicants } \\
\text { by the Board }\end{array}$ & Yes & Yes & Yes & Yes \\
\hline $\begin{array}{l}\text { Prior posting of the list of } \\
\text { applicants for all members } \\
\text { to see }\end{array}$ & Yes & Yes & Yes & No \\
\hline $\begin{array}{l}\text { Resignation of proponent } \\
\text { and/or sponsors in case of } \\
\text { rejection }\end{array}$ & Yes & Yes & Yes & No \\
\hline $\begin{array}{l}\text { Support campaign by } \\
\text { proponent and/or sponsors }\end{array}$ & Yes & Yes & Sometimes & No \\
\hline $\begin{array}{l}\text { Preliminary access to club } \\
\text { activities before admission }\end{array}$ & No & No & Sometimes & Yes \\
\hline $\begin{array}{l}\text { Existence of a specific } \\
\text { committee to examine } \\
\text { applications }\end{array}$ & No & No & Yes & Yes \\
\hline $\mathrm{CV}$ of the applicant required & No & No & Yes & Yes \\
\hline $\begin{array}{l}\text { Induction/introduction } \\
\text { ceremony for new members }\end{array}$ & Yes & Yes & No & No \\
\hline $\begin{array}{l}\text { Secrecy of the rites of the } \\
\text { ceremony }\end{array}$ & Yes & No & No & No \\
\hline Women allowed in the club & $\begin{array}{l}\text { No } \\
\text { (Very } \\
\text { occasionally in } \\
\text { the guest } \\
\text { salon) }\end{array}$ & $\begin{array}{l}\text { No } \\
\text { (Only in } \\
\text { the guest } \\
\text { salon) }\end{array}$ & $\begin{array}{l}\text { Only for } \\
\text { soirees } \\
\text { (Wives and } \\
\text { other } \\
\text { female } \\
\text { guests) }\end{array}$ & $\begin{array}{l}\text { A few women } \\
\text { are members } \\
\text { and wives of } \\
\text { male } \\
\text { members are } \\
\text { often invited }^{a}\end{array}$ \\
\hline
\end{tabular}

${ }^{a}$ Officially, Rotary clubs can be masculine ( 9 out of 30 in Milan), feminine (none) or mixed ( 21 out of 30 ). However, in 2001, only 4.6 per cent of Milan's 2140 Rotarians were women. The RC Milano counted 5 women out of 209 members, and the RC Milano Sud 4 out of 109 


\section{Club Social Capital as Mobilisable Resource}

In order to better understand how social capital is formed and reproduced within social clubs and the Rotary, one must also analyse, for each of these institutions, the interindividual relationships between its members and the different ways the latter perceive and mobilise one another as resources for action. Doing so requires including a micro-sociological focus (Bourdieu \& Coleman, 1991; Coleman, 1990).

Each social or Rotary club can function as an appropriable organisation, a network mobilisable for multiple purposes. Yet, the possibilities of cooperation that each club offers to its members depend on its particular combination of elementary forms of social capital (Bagnasco, 1999, 2002). Consider the Clubino. As a group of dense mutual acquaintance whose members are often connected by strong ties, and as an institution exerting normative control over them (with sanctions in case of serious misconduct), it endows its members with some social capital of solidarity (Pizzorno, 1999). The latter manifests itself in two complementary forms: external trust (reputation) and internal trust (cohesion). Through the first one, belonging to the club can serve as tacit guarantee towards potential clients or business partners, because the institution is known for requiring certain behaviours and moral standards from its members. The second form played a key role in the 1990s when the anti-corruption investigations of operation Mani Pulite generated conflicting dynamics between internal and external trust. When evoking this period, a Clubino board member insisted on the 'values' that found or should found the identity of each member. He presented thefts and acts of corruption, brought to light by the investigations, less as infractions of the law than as breaches of these values, associated with the 'business world' and with an ethic of capitalism supposed to be a shared feature of Clubino members. According to this line, deviants must be excluded in order to preserve the reputation and honour of the group of peers. This happened in the form of the resignation of each accused member, perceived by the others as a last act of solidarity - an individual sacrifice in order to avoid defiling the collective name. Yet, the club also rejected the resignations of some members, whom it considered were the victims of judicial persecution, thus privileging internal cohesion-and the credit bestowed upon members when coopting them-over the defence of external trust.

Moreover, besides solidarity established through peer control, the club allows for the development of what Alessandro Pizzorno calls social capital 
of reciprocity at the interindividual level. Club life creates durable relations that foster cooperation between members for common purposes and the pursuit of mutual interests, including business partnerships. This vocation of the club is all the more efficient as it is relegated to the background.

It is physiological that, between members of the same club, we trust each other more. Thus, if someone needs to do some business or make some other professional agreement and, among the members, there is someone else into that line of work ... of the thing that interests us... It comes spontaneously to call on him, to invite him to the table where we are talking about it at that moment. One does not go to the club to build work connections, absolutely not. To the contrary, it is important to specify: one goes there to relax. But it's clear that we all work, unfortunately ... and thus we can't not speak about work from time to time. Obviously, it can happen. In a very spontaneous way, a very light way. (G., 34, insurance executive, Clubino member)

Club life allows each member to consolidate and expand his contact list, thus intensifying the circulation of information concerning his professional reputation. However, social club members scrupulously deny any intention that could make their participation appear as an explicit strategy of seeking personal benefit. This could compromise affinity-based trust and a social capital of solidarity that is officially above any calculation.

By contrast, the 'Guiding Principles' of the Rotary clubs explicitly describe the organisation's attempt to create a complex sociability structure almost ex nibilo. Its vocation for constituting intra and interprofessional networks that are useful to its members is stated in its statutes. It is also encouraged through the talks that members regularly give on topics most often related to their occupations. One can clearly observe an opposition between social club members, who consider themselves well 'established' as an upper class (and whose social identity is solidified), and Rotarians, who see themselves as experiencing a process of upward mobility and accumulation of all forms of capital, including social capital, and openly display their aspirations and utility-oriented relation to sociability.

Understood as philia, sense of belonging to a group of peers that are equally deserving on the professional level, and not like the semi-familial agape that characterises social clubs (Boltanski, 2012), 'friendship' is mostly conceived by Rotary members as an extra benefit that optimises the conditions for the exchange. It is a facilitating element thanks to which the 
civic and philanthropic ideal of Rotarian 'service' (Camus-Vigué, 2000) can be achieved. This ideal is firstly centred on the services that members render each other, then on help towards external causes. It combines a belief in the trickling down of social capital with a form of paternalistic altruism, to which civilising virtues are attributed (Silver, 1989).

One helps each other inside, among us, so that we can then have the conditions to have an effect on the outside. (...) It is fair that, within the list of members, anyone, even someone I don't know, can ask me for something for which I can contribute my professional know-how. It is with pleasure that I give him the possibility to obtain the information he is looking for and the answer he wants. I too have-quote unquote- 'profited' from it. (...) I just used to ask: 'Can you give me your professional opinion, which I can trust (and which I'm even eager to give back when my turn comes)?' Because one should be able to give back. (...) And I think this is important. Because the quality of life also depends on access to services and to reliable, quality information. (U., 77, former chairman of a large electric company, member of the RC Milano Sud)

Through this sharing of competences, the Rotary converts cultural capital into social capital, constituting a (private and collective) portfolio of services for its members (and secondarily for all), and contributes to integrating its adherents simultaneously into the local elites and into their professional milieu. Rotarians sometimes nuance this prevalent representation of the link that unites them by evoking a logic of gift and delayed countergift, first among themselves and then vis-à-vis the world. However, the explicit emphasis that the Rotary places on utility, its social engineering mission and paternalistic openness towards the outside-which it shares with the Lions Club-distinguish this organisation from upper-class social clubs, such as the Unione, the Clubino and (to a lesser extent) the Giardino.

\section{Competing Conceptions of Legitimate Elite SOCIABILITY}

Finally, uses and representations of elite sociability take on their full meanings through logics of mutual distinction between clubs. When Clubino members described their club, they insisted on the paradoxical relationship of filiation and breach that it has with the particular elitism and the traditionalism of the Unione. When representing this relationship, they 
often resorted to self-mockery and irony. True, the Clubino perpetuates traditional sociability, with drinks at the bar between posh tie-wearing white men, large salons with red velvet drapery, counts of black and white balls during admission votes, cigars smoked around a whist or carom billiards table, and discussions by a crackling fireplace. Yet, members do not perceive club life as the mere celebration of inherited prestige. Clubino members can dispense with the ritual maintenance of their status since the latter is already updated by their participation in economic power. Therefore, they mark their differences with the Unione by laying emphasis on humour and play as defining features of their group's recreational sociability. Self-mockery here functions at once as an ostentatious refusal of the formalism associated with older forms of symbolic capital and as the best proof that Clubino members nevertheless possess enough of them to reflexively laugh about it. Thus, they can afford 'not to take themselves too seriously' and get excited 'like everyone else' for the games of the main Italian soccer teams (which they own). But irony also contributes to stigmatising the 'out-dated' position of the Unione, which primarily resorts to the old forms of capital to perpetuate its legitimacy. To the extent that it subverts a hierarchy of prestige exclusively based on ancient belonging to the ruling classes, sense of humour at the Clubino is thus both an expression and a vector of symbolic domination within elite sociability. It is no surprise, then, that its members identify this rupture in the symbolic order with the founding event of the club:

This spirit, we try to keep it alive: the spirit that is a bit that of the Milanese Scapigliatura of the nineteenth century; which means we make a bit fun of one another. Whereas, at the Unione, let's say they are a bit more serious from this point of view. They laugh a bit less, even less. That's not negative per se, of course. However, the spirit of the Clubino, which, as you know, was born from a split with the Unione, was a bit that of ... as one says in a vulgar way, to fuck around: to have fun, to tease each other a little, etc. We always laugh when people says that the club, the Clubino, is a cultural club. Because there is nothing cultural about it. Although we sometimes organise an evening with a journalist or a musician who comes to speak... But we still try to keep a spirit a bit more exuberant. (A., 50, business lawyer, board member)

The will to live, the exuberance, the cheerfulness ... the grandeur. And, in fact, the blissful possibility-more or less blissful, of course it depends on perspectives - to live a privilege without feeling its weight too much. (F., 40, president of a sport club, Clubino board member) 
Through the joint celebration of 'grandeur' and 'exuberance', the Clubino reasserts and legitimises its dominant position among clubs: that of elites who possess 'naturally' and 'innately' (because they inherited them) all forms of capital. Indeed, on one side, it targets the 'traditionalist' seriousness of the moneyless aristocrat who spends time at the Unione and in nobility associations to cultivate the prestige of his old name. On the other side, it derides the 'nouveau riche' who showcases his wealth and believes that everything can be bought, the cultural goodwill (Bourdieu, 1984) of associations who regularly organise lectures, and the Rotarian prospecting for social capital.

However, in the case of the Unione and the Clubino, relations of opposition between the two institutions do not prevent certain families and even some individuals to belong to both clubs at the same time. For a family to have potential access to the two most prestigious clubs allows it to circumvent one unwanted effect of the strong integration between familial and institutional sociability: the likely repercussion of a family feud on the possibility of being co-opted. Indeed, the common origin of the Unione and the Clubino means numerous families have had their men dispatched between the two institutions. This situation, which combines competition and strong ties between the two clubs, has also given rise to a rich tradition of inter-club sociability. The latter includes historic rivalries in alpine skiing and tennis, with two annual tournaments during which representatives of each club defy their counterparts. Notably, distinction vis-à-vis the Giardino is also marked by its exclusion from these events featuring 'noble sports' (Saint Martin, 1989), whereas it takes part in inter-club contests in more bourgeois and sedentary leisure activities such as billiard and bridge.

The history and structural position of the Società del Giardino are marked by its (failed) attempts to measure itself to the other two Milan social clubs and to be treated as equal by them. As these history and position inform its organisation and the representation of it held by its members, its identity is primarily relational. But the search for distinction appears even more violently when one ventures to evoke differences with the Rotary clubs. The mere idea of such comparison provoked the fury of one interviewee:

There is nothing similar: the nature of this association has nothing to do with the Rotary! The Rotary and the Lions are clubs ... are ... service clubs. They don't have their own place! (F., architect, 70, former president of the Giardino) 
Thus, Giardino members associate the Rotary with the less prestigious and socially selective Lions club in the same way as, in the other social clubs, many members condemn sociability practices that are common to the Giardino and the Rotary.

Indeed, members of the social clubs clearly distance themselves from the practices of the Rotary. They particularly criticise what they deem to be the following features: (1) the 'artificiality' of a form of sociability that they find laborious because it plans and organises friendships outside the genuineness of pre-existing or serendipitous connections; (2) its explicitly utilitarian motivations; and finally (3) its consideration of professional merits when selecting new members. They do not hesitate to present the latter in an exaggerated way:

The vocation of the Rotary: to have the best of each professional category. From the great lawyer to the great janitor, one might say. (G., 34 , insurance executive, Clubino member)

I was for a certain time a member of the Rotary of Milan... I don't know of which one exactly: you know that there are several, organised in districts... And I resigned after a while because they, on the other hand... the Rotary, and a little bit the Giardino as well, admit in fact members precisely with the idea of gathering them to be mutually useful to each other, including and especially in the domain of work. (...) And people do not really get to know each other, precisely because the assumption is that... is not so much to socialise as to establish contacts that can be useful. (G., 50 , business lawyer, Clubino board member)

The polarisation described above does not prevent some members of social clubs to also belong to the Rotary. But they consider their membership to the latter as an incidental, additional affiliation that does not define their identity. Contrary to the majority of Rotary affiliates, they never call themselves 'Rotarians'. In addition, the dominated position of Rotarians manifests itself by the views they hold about social club sociability, which often combine fascination and ignorance about the organisation of these clubs.

Finally, one can observe strategies of distinction within the Rotary itself. If the valuation of 'individual merit' is officially at the centre of Rotarian ideology, the organisation has in fact always been attached to class, tightly circumscribing how it understands merit: almost only managers, professionals and business-owners are effectively represented in it. Thus, the multiplication of Rotary clubs throughout the years is considered by the 
members of the oldest Milan RCs as decreasing the value of belonging to the organisation. In response to such supposedly excessive openness, they emphasise their longer history and their more exclusive character. In return, the other RCs insist on formal equality between clubs, while referring to the prestige of the Rotary in general and often illustrating this prestige through examples drawn from the oldest clubs - following a strategy of symbolic participation and capitation of symbolic capital.

\section{Conclusion: Social Capital as Will AND REPRESENTATION}

The excessive polysemy of the notion of social capital has caused multiple controversies, marked at times by calls to abandon the concept, at other times by new attempts at synthetic theoretical modelling. Rather than seeking to prematurely unify different forms of social capital under an all-encompassing model, the perspective presented in this chapter focuses on differences in the way in which actors and institutions themselves construct and desbribe their distinctive forms of social capital. In order to do so, it considers the case of Milan's economic elites to analyse the competitive struggle to define the most legitimate manner to establish social connections and friendship ties.

Indeed, ways of cultivating social capital are not distributed randomly. As with the opposition between 'docte' (scholastic) and 'mondain' (effortlessly elegant) relationships to cultural capital identified by Bourdieu (1984: 70 ), disagreements over the best way of accumulating and managing social capital, as well as benefiting from it, depend on an array of conditions of acquisition which are unequally distributed in social space, and unequally distinctive or stigmatised. At the Circolo dell'Unione and the Clubino, gatherings of nobility and old money dynasties, social capital (as it is fostered by the club) is conceived as a quasi family-based collective resource. Its cultivation is experienced and presented as disinterested, confidential and with no other primary purpose but leisure. In contrast, Rotary clubs are more recent institutions aggregating upwardly mobile upper and upper-middle classes. Their members experience the accumulation of social capital as an individual and explicitly instrumental investment: membership is based on professional status and geared towards reciprocal exchanges of 'services'.

In-depth interviews with club members thus uncover the differentiated distribution of connections and relationships to social capital within Milan's elite. They also reveal the game of mutual evaluation by which 
different groups of actors distinguish themselves through the distinctions they operate between good and bad manners of maintaining and accumulating social ties. This chapter has highlighted the contribution of these competing symbolic representations to the dynamics of social capital among the urban rich and super-rich.

\section{Notes}

1. We would like to thank Marco Oberti, Anne Raulin, Tommaso Vitale, Diana Mauri, Silvana Mauri Ottieri, Rosellina Archinto, Lina Sotis, Enzo Mingione, Mathieu Richard, Bart Wissink, Sin Yee Koh and Ray Forrest for their support and advice in carrying out the research and writing for this chapter.

2. Since the coming into force of the Constitution of the Italian Republic (on January lst, 1948), nobility titles are no longer officially recognised by the State.

3. In 2001-2002, Milan's social clubs (especially the Unione and the Clubino) were officially against accepting professional politicians as members. This was because they considered that elected officials are inherently controversial figures, and because many clubmen from the aristocracy and the old bourgeoisie had very little sympathy for Milanese tycoon and Italian Prime Minister Silvio Berlusconi and his associates. Nevertheless, several city officials were close to the clubs. For instance, in the Moratti family (whose men are at the Clubino), Milly Moratti was a left-wing city councillor from 2001 to 2011, while her (right-wing) sister-in-law Letizia Moratti was Mayor of Milan from 2006 to 2011.

4. Out of 16 founding members, five were also members of the Unione and seven would join it later.

5. At the Unione, in 2001, rates were 9 per cent and 3 per cent, respectively.

\section{REFERENCES}

Baltzell, E. D. (1987 [1964]). The protestant establishment: Aristocracy and caste in America. New Haven: Yale University Press.

Bagnasco, A. (1999). Teoria del capitale sociale e «political economy» comparata. Stato e mercato, 57, 351-372.

Bagnasco, A. (2002). Il capitale sociale nel capitalismo che cambia. Stato e mercato, 65, 271-304. 
Boltanski, L. (2012 [First French edition: 1990]). Love and justice as competences: Three essays on the sociology of action. Cambridge: Polity.

Bourdieu, P. (1980). Le capital social: Notes provisoires. Actes de la recherche en sciences sociales, 31, 2-3.

Bourdieu, P. (1996 [First French edition: 1989]). The state nobility: Elite schools in the field of power. Redwood City: Stanford University Press.

Bourdieu, P., \& Coleman, J. (Eds.). (1991). Social theory for a changing society. Boulder: Westview Press.

Camus-Vigué, A. (2000). Community and civic culture: The rotary club in France and the United States. In M. Lamont \& L. Thévenot (Eds.), Rethinking comparative cultural sociology: Repertoires of evaluation in France and the United States (pp. 213-228). Cambridge: Cambridge University Press.

Coleman, J. (1990). Foundations of social theory. Cambridge, MA: The Belknap Press of Harvard University Press.

Cousin, B., \& Chauvin, S. (2010). La dimension symbolique du capital social: les grands cercles et Rotary clubs de Milan. Sociétés Contemporaines, 77, 111-138.

Cousin, B., \& Chauvin, S. (2012). L'économie symbolique du capital social: notes pour un programme de recherche. Actes de la recherche en sciences sociales, 194, 96-103.

De Saint Martin, M. (1989). La noblesse et les «sports» nobles. Actes de la recherche en sciences sociales, 80, 22-32.

De Saint Martin, M. (1993). L'espace de la noblesse. Paris: Métailié.

Khan, S. (2012). The sociology of elites. Annual Review of Sociology, 38, 361-377.

Milne-Smith, A. (2011). London clubland: A cultural history of gender and class in late-Victorian Britain. London: Palgrave Macmillan.

Pinçon, M., \& Pinçon-Charlot, M. (1989). Dans les beaux quartiers. Paris: Seuil.

Pinçon, M., \& Pinçon-Charlot, M. (1998). Grand fortunes: Dynasties of wealth in France (First German ed.). New York: Algora.

Pinçon, M., \& Pinçon-Charlot, M. (2007). Les ghettos du gotha: Comment la bourgeoisie défend ses espaces. Paris: Seuil.

Pizzorno, A. (1999). Perché si paga il benzinaio: nota per una teoria del capitale sociale. Stato e mercato, 3, 373-394.

Ponthieux, S. (2006). Usages et mésusages du capital social. In A. Bevort \& M. Lallement (Eds.), Le capital social: Performance, équité et réciprocité (pp. 89-105). Paris: La Découverte.

Portes, A. (2010). Social capital. In Economic sociology: A systematic inquiry (pp. 27-47). Princeton: Princeton University Press.

Silver, A. (1989). Friendship and trust as moral ideals: An historical approach. Archives européennes de sociologie, 30(2), 274-297. 